\title{
EVIDENCE THAT RENAL SODIUM EXCRETION BY NORMAL HUMAN SUBJECTS IS REGULATED BY ADRENAL CORTICAL ACTIVITY ${ }^{1}$
}

\author{
By ALEXANDER LEAF aNd WILLIAM T. COUTER \\ WITH THE TECHNICAL ASSISTANCE OF MARION LUTCHANSKY AND ANN REIMER
}

(From the Department of Internal Medicine, The Medical School, University of Michigan, Ann Arbor, Mich.)

(Received for publication February 25, 1949)

When a normal human being is placed on a very low sodium intake, the urinary sodium decreases to very small amounts. Contrariwise, with large sodium intakes, the urinary sodium increases proportionately. In both cases, the normal body content of sodium is quickly reestablished. How is this conservation of body sodium effected?

The depletion of body sodium that occurs in adrenalectomized animals and in patients suffering from Addison's disease, and the retention of sodium with reestablishment of balance that accompanies the administration of adrenal cortical extracts, leaves no doubt about the fundamental position of a cortical hormone in the regulation of body sodium in the abnormal states just mentioned (1-5).

Since there is a paucity of information regarding the regulation of body sodium content in normal subjects who receive large variations in intake of sodium, our studies were designed to learn the role of adrenal cortical activity in this regulation in normal human beings.

Even though it is not possible to determine directly the concentration of the specific hormone in the blood, nevertheless a number of methods that serve as indirect indices of adrenal cortical activity are available. It was surmised that by creating a need to conserve body sodium in the presence of large shifts in intake, evidence of other adrenal cortical effects, especially on protein metabolism, might be elicited. If such evidence of adrenal cortical activity can be obtained by the requirement to conserve sodium, such data would greatly strengthen the hypothesis that in the normal subject this conservation of body sodium is in fact mediated through an increased or decreased adrenal cortical activity (6).

1 This study was aided by a grant from the United States Public Health Service.

\section{EXPERIMENTAL}

Three normal young adults were subjects for this study: one male resident physician (W. C.), age 32; one male medical student (E. W.), age 22 ; and one female graduate student (M. L.), age 22. The plan of study was to place the subject on an adequate caloric and protein dietary intake with a very low sodium content (approximately $200 \mathrm{mgs}$. or $9 \mathrm{mEq}$. daily) throughout the study, and at definite periods to administer orally large amounts of sodium as sodium chloride or sodium citrate.

This was accomplished by using a constant daily diet. The water intake was uncontrolled as its sodium content was found to be insignificant by analysis. The subjects went about their usual daily activities avoiding severe exertion and sweating. Urine and stool collections were made daily and the nude body weight was recorded each morning before breakfast and after emptying the bladder. A special human balance having a sensitivity of $5 \mathrm{gms}$. was used. Each 24 hour urine was collected with toluene as a preservative and was analyzed separately on the day following the collection. Stools were promptly treated with alcohol and made acid with glacial acetic acid or sulfuric acid, dried in an oven at $50^{\circ}$ to $60^{\circ} \mathrm{C}$., weighed, blended in a Waring blender and combined into two or three day periods with suitable aliquots taken for analyses. Subjects were fed from the same lot of food throughout the period of study and a sample day's diet was dried, blended and analyzed.

When a constant body weight was achieved and the urine sodium and chloride excretions had reached a minimum on this low sodium intake, $11.0 \mathrm{gms}$. or 478 mEq. of sodium were administered orally as the chloride (28.0 gms. of sodium chloride) or citrate (46.88 gms. of sodium citrate) daily for three days. Fasting blood samples were obtained with a minimum of stasis at the beginning and end of the study, and before and after each period of sodium administration. Samples for potassium and carbon dioxide content were drawn under oil and the former kept refrigerated until the serum was separated from the cells with no hemolysis occurring.

Hematocrit (packed red cell volume) was estimated by the method of Wintrobe (7). Sodium analyses were done on serum, urine, diet, and stools by means of the Butler and Tuthill (8) modification of the uranyl zinc acetate method of Barber and Kolthoff. For urines of very low sodium content a modification involving $50 \mathrm{cc}$. 
aliquots and removal of potassium as well as phosphate was utilized (9). Potassium was determined in serum, urine, diet and stool by a modification of the platinic chloride micro colorimetric method of Shohl and Bennett (10). Chloride analyses of serum were done using the method of Van Slyke and Sendroy (11). Urine, stool, and diet chloride determinations were done by a modification of the Volhard-Harvey titration (12). Urinary ammonia was determined by the aeration method of Van Slyke and Cullen (13). Total urine, diet and stool nitrogen were determined by the Kjeldahl method for macro analysis (14). Urine creatinine was measured by the alkaline picrate method of Folin (15) and in subject E. W., also by the modification of Bonsnes and Taussky (16). Agreement between the very simple method of Folin and the more refined latter method was surprisingly good. The modification of Bonsnes and Taussky was also adopted for serum creatinine determinations. Blood urea nitrogen was estimated by the method of Gentzkow (17) while for urine urea the method of Barker (18) was utilized. Urine uric acid determination was done by the total color method of Buchanan, Block, and Christman (19). Carbon dioxide content of the serum was determined by the method of Van Slyke and Neill (20). Serum protein analyses were done by the micro Kjeldahl method and the steam distillation of Goebel (21). Urine, stool and diet were analyzed for phosphate by the colorimetric method of Fiske and Subbarow (22).

The aliquots of diet and stools were dry ashed in such a manner that analyses could be made for sodium, chloride, potassium, and phosphorus on a single preparation. This was accomplished by mixing the aliquot with an excess of calcium hydroxide until definitely alkaline, drying and then ashing in the muffle furnace at $400^{\circ} \mathrm{C}$. for 48-72 hours. The residue was washed with water and filtered. The filtrate containing the sodium, chloride, and potassium was made up to volume in a volumetric flask from which aliquots were taken for analysis. The washed residue was later dissolved with dilute nitric acid to yield phosphate. Values for chloride of diet and stool obtained by this method were the same as values obtained by wet ashing the sample.

Inulin clearances were done by the Harrison modification of the method of Alving, Rubin, and Miller (23) following a single intravenous injection of 10-20 gms. of inulin.

The values for dietary intake of calories, carbohydrate, fat and protein were obtained from Bowes and Church (24) and U. S. Department of Agriculture Circular Number 549. The calculated values for sodium, chloride, potassium and phosphorus content of foods were obtained from McCance and Widdowson (25). In addition, analyses were made on complete diets (with the exception of the butter) for total nitrogen, total phosphorus, sodium, chloride, and potassium. The agreement between actual analyses and calculated values was surprisingly good. Thus in subject M. L.'s diet the calculated and analyzed composition was respectively: nitrogen-12.3 and 11.2 gms.; sodium-8.7 and $8.3 \mathrm{mEq}$; chloride ${ }^{2}-21.0$ and $22.8 \mathrm{mEq}$; and potassium- 89.7 and $94.0 \mathrm{mEq}$. Similarly in subject E. W.'s diet the calculated and analyzed composition was respectively: nitrogen-14.3 and 15.0 gms.; sodium-9.1 and $9.4 \mathrm{mEq}$.; chloride-24.4 and 24.9 mEq.; and potassium-100 and $100 \mathrm{mEq}$. The dietary intake figures recorded for subjects $M$. L. and E. W. in Tables II and III are values obtained by our analyses for sodium, chloride, nitrogen, potassium and phosphorus as no diet changes were made and all the food was eaten. In subject W. C. who frequently rejected portions of his diet, such portions were weighed and their composition as obtained from the above-mentioned food composition tables was subtracted from the total calculated content of the diet, and each day's intake is recorded in Table I.

\section{RESULTS}

The complete data of these studies are shown in Tables I, II and III.

The electrolyte and weight changes are the subject of a separate report (6). However, it is important to the present discussion to point out that with the curtailment of sodium intake to about $9 \mathrm{mEq}$. daily there occurred a sharp initial weight loss of about 2 kilograms in each subject. This weight loss was associated with a negative sodium and chloride balance (Figure 1 illustrates these changes in subject E. W.). After approximately one week of this low sodium regimen the urinary loss of sodium and chloride was reduced to extremely minute amounts ( 1 to $2 \mathrm{mEq}$. of sodium in the 24 hour urine specimen) and the weight became stabilized. Under the stimulus of such severe sodium restriction the kidneys conserve sodium maximally.

On administration of the large amounts of sodium (480 mEq. daily for three days) as the sodium chloride or sodium citrate salts there was with each a significant weight gain. None of the subjects showed clinical edema, however. The urinary excretion of sodium lagged in every case so that only by the last day of the sodium administration had the output attained the daily intake level.

With these changes in weight and in urinary excretion of sodium and chloride, accompanying

2 Interestingly the diet analyses, not including "Lonalac," yielded nearly equivalent values for sodium and chloride. The addition of "Lonalac" (Mead Johnson and Co., Evansville, Indiana), which contains supplementary potassium chloride, resulted in the actual higher values of chloride. 
RENAL SODIUM EXCRETION IN NORMAL SUBJECTS

\begin{tabular}{|c|c|c|c|c|c|c|c|}
\hline \multicolumn{2}{|c|}{ 范 } & & 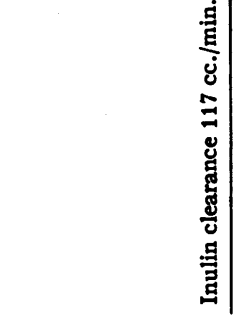 & 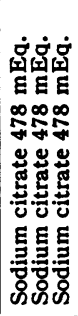 & & 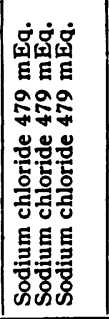 & 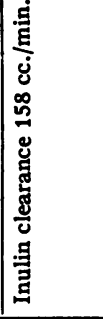 \\
\hline \multirow{4}{*}{ 递 } & z & $\dot{s}$ & 年 & 可司 & א్心 & | & 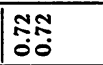 \\
\hline & $\forall$ & ब1ำ & $\stackrel{m}{\exists=}=$ & พูพิึู & भुmmogo: & 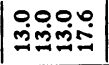 & $\mid \begin{array}{l}\infty \\
+\infty \\
+\infty+\infty\end{array}$ \\
\hline & $\overline{0}$ & वृ & क्वें। & 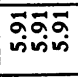 & 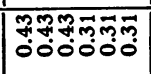 & \begin{tabular}{|l|}
0000 \\
00000
\end{tabular} & 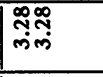 \\
\hline & $\ddot{z}$ & बi & 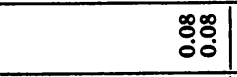 & $\begin{array}{l}8880 \\
0000\end{array}$ & $\begin{array}{l}\text { mथM } \\
000070\end{array}$ & 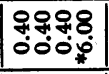 & 萬 \\
\hline \multirow{7}{*}{ 营 } & $\forall$ & वां & 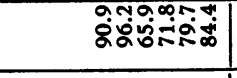 & 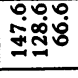 & 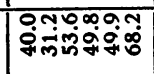 & $\mid$ & | \\
\hline & $\overline{0}$ & बี & 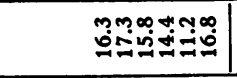 & 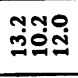 & 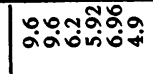 & \begin{tabular}{|l|l|}
$\mid$ \\
\end{tabular} & 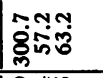 \\
\hline & $\ddot{z}$ & का & 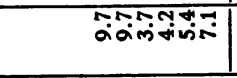 & 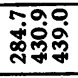 & 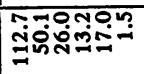 & 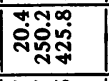 & 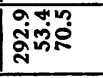 \\
\hline & 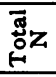 & $\dot{s}$ & 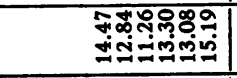 & 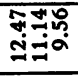 & |8̊ำ & 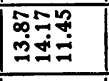 & 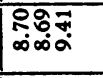 \\
\hline & 要 & ขึ่ & omañ⿻十 & : & 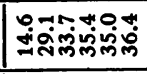 & mon & 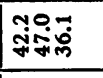 \\
\hline & 密z & $\dot{\varepsilon}$ & 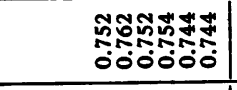 & 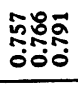 & 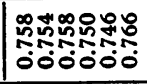 & 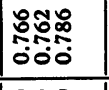 & 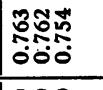 \\
\hline & $>$ & i & 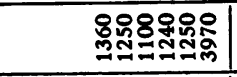 & 유ำำำ & 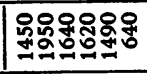 & \&్దిశ్రిర్లి & 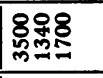 \\
\hline \multirow{6}{*}{ 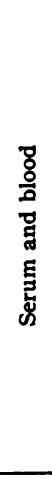 } & 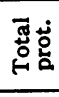 & 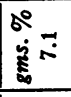 & $\cong$ & & $\cong \quad \cong$ & & in $\stackrel{m}{s}$ \\
\hline & $\begin{array}{l}\mathrm{z} \\
\mathrm{s} \\
\end{array}$ & 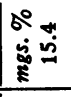 & $\stackrel{\ddot{b}}{\circ}$ & & 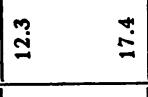 & & $\infty$ \\
\hline & ర్ర & $\frac{5}{4}$ & : & & $\begin{array}{ll}0 \\
\stackrel{i}{N} & \stackrel{n}{d} \\
\end{array}$ & & $\stackrel{\ddot{\sim}}{\ddot{\sim}}$ \\
\hline & $: 4$ & $\begin{array}{ll}n \\
5 \\
5\end{array}$ & $\underset{\substack{\infty \\
+}}{ }$ & & 旁 & $\underset{+\infty}{+\infty}$ & \\
\hline & $\bar{U}$ & 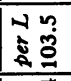 & îj & & 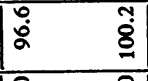 & $\begin{array}{l}m \\
\infty \\
\infty\end{array}$ & 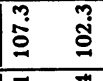 \\
\hline & zే & बهं & 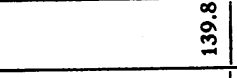 & & $\mid \begin{array}{ll}0 \\
\dot{g}\end{array}$ & $\overrightarrow{\bar{a}}$ & 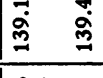 \\
\hline \multirow{5}{*}{ 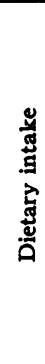 } & 4 & 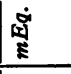 & 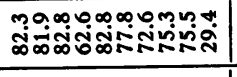 & 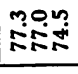 & 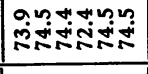 & 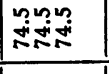 & $\mid$ \\
\hline & $\overline{0}$ & वां & 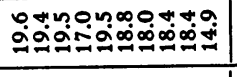 & 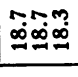 & 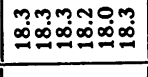 & 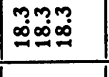 & | \\
\hline & zீ & 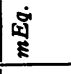 & 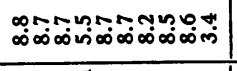 & 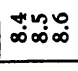 & 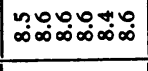 & 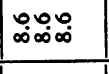 & åd \\
\hline & $z$ & है & 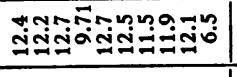 & 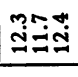 & 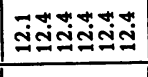 & 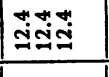 & म표표 \\
\hline & & : & 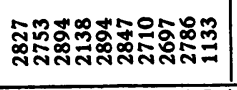 & స్విస్తిం్స్ & | & 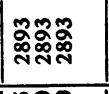 & | \\
\hline \multicolumn{2}{|c|}{ 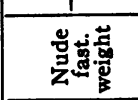 } & is & 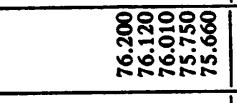 & 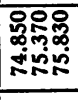 & 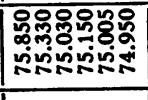 & \begin{tabular}{|l|l} 
\\
\end{tabular} & 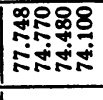 \\
\hline \multicolumn{2}{|c|}{ 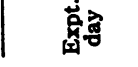 } & & 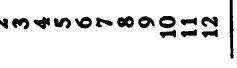 & mジ & 요ำกㅈ & สกสี & ละสิกั \\
\hline
\end{tabular}




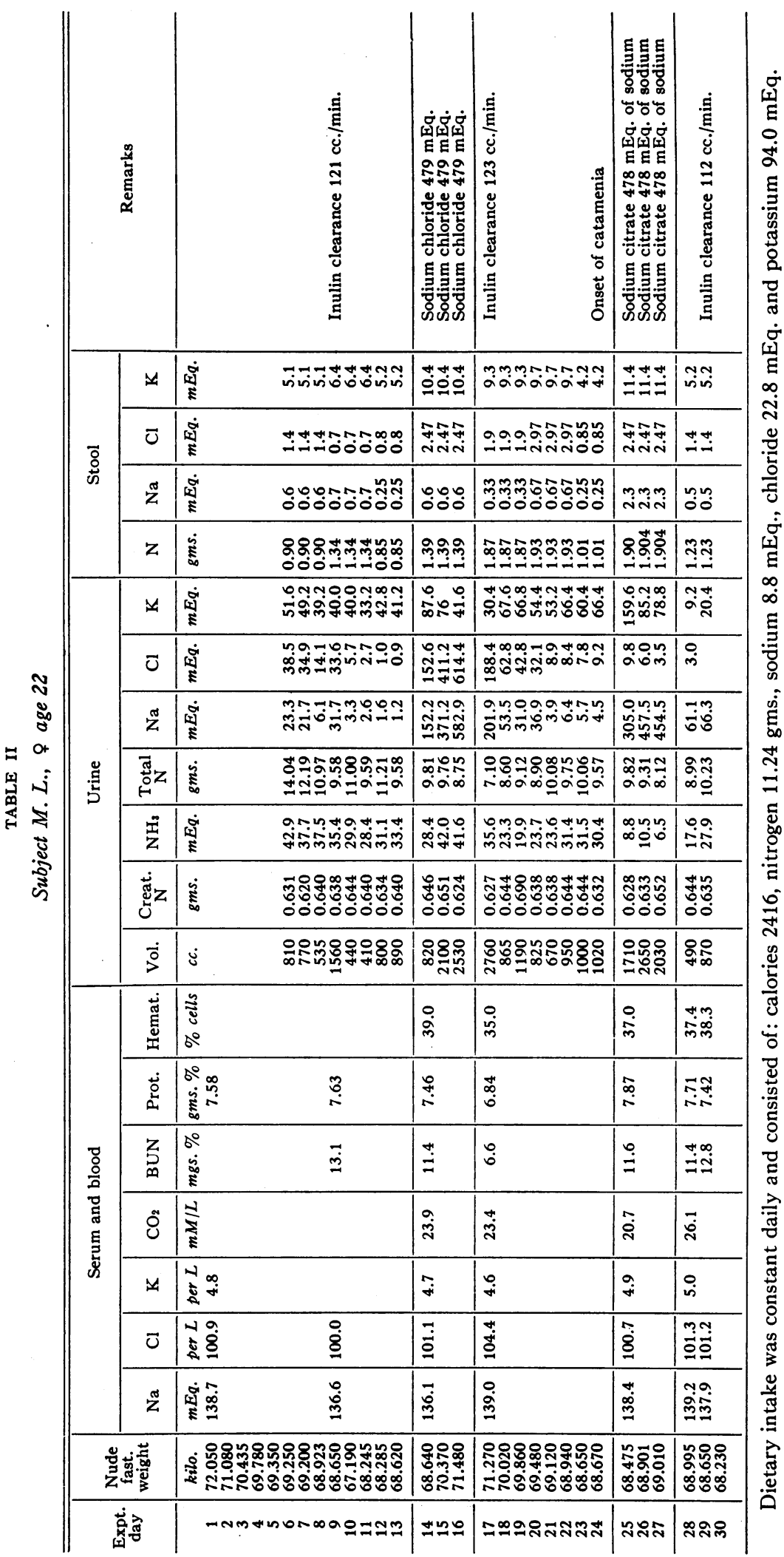




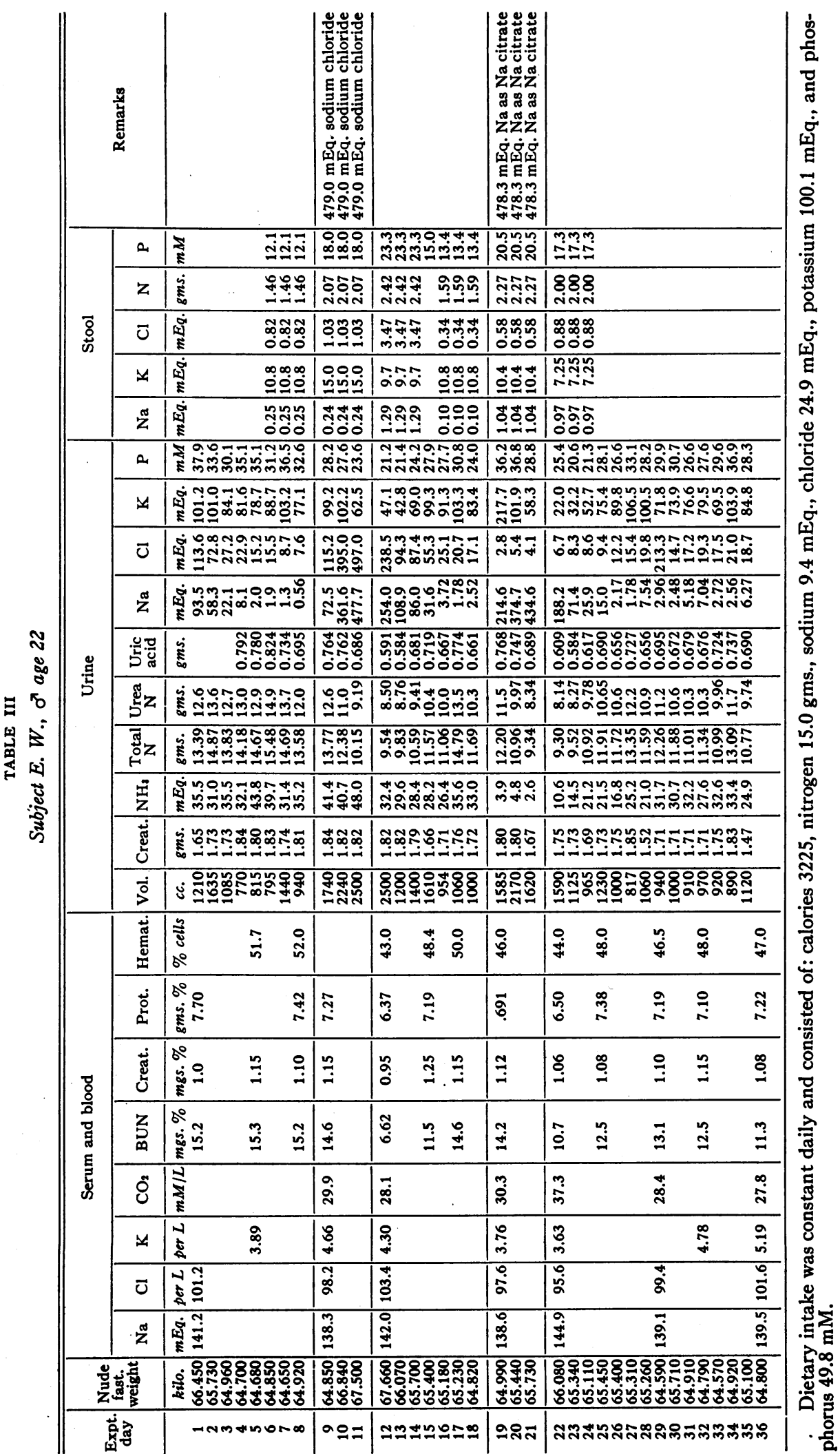




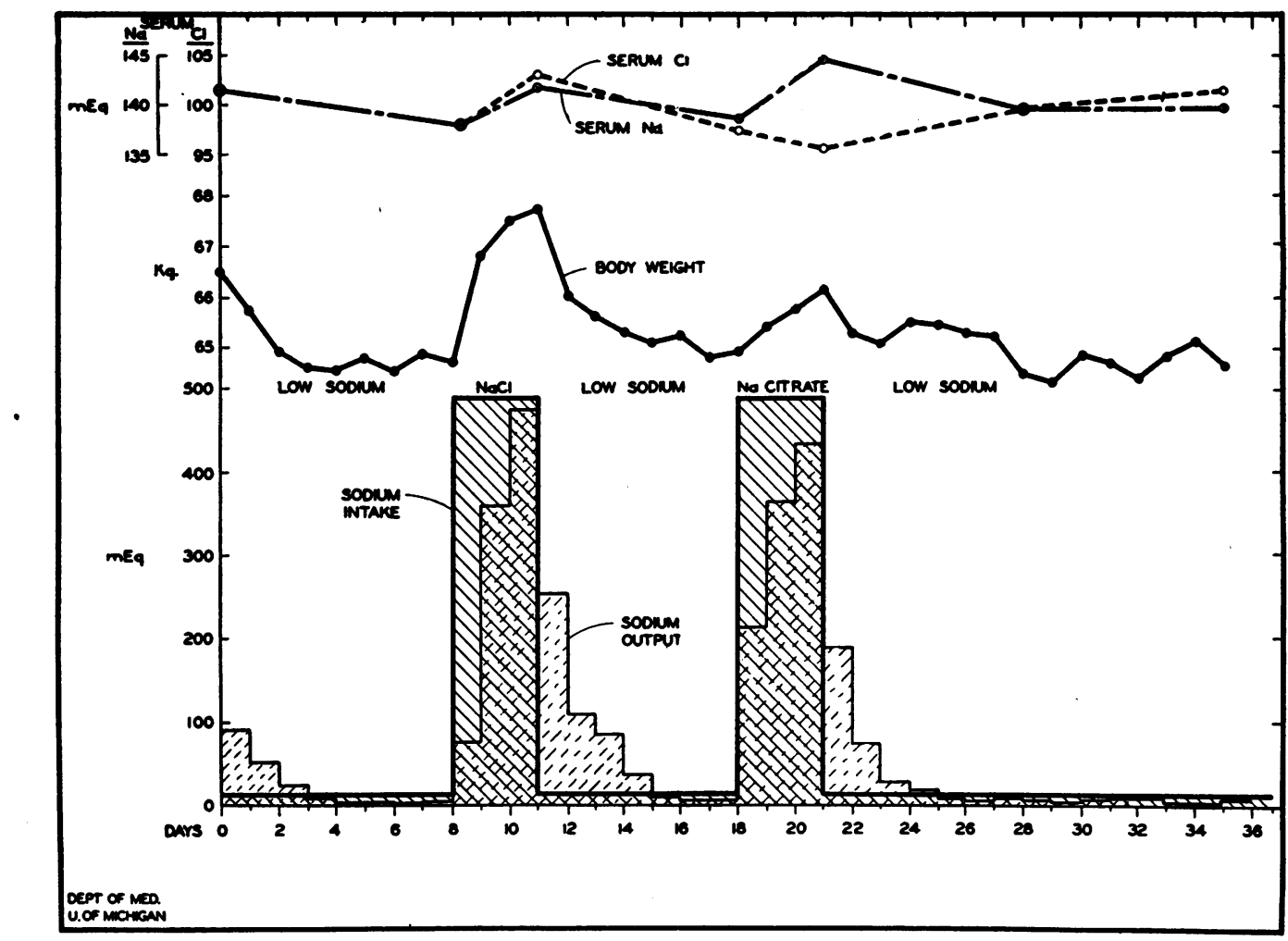

Fig. 1. To Show Changes in Body Weight, Serum Sodium and Chloride Concentrations, and Sodium Balance in Subject E. W.

changes were noted in extracellular fluid composition. The sodium restriction uniformly caused a small but significant lowering of serum sodium concentration and elevations occurred on administration of sodium. Serum chloride values followed a similar trend though less uniformly. Administration of the sodium citrate caused a rise in serum sodium in each case, a decrease in serum chloride in two cases and a rise in serum $\mathrm{CO}_{2}$ content. $\mathrm{A}$ parallel rise in serum sodium and chloride followed sodium chloride administration. With the sodium citrate administration urinary sodium excretion rose sharply to high levels but urinary chloride loss was, if anything, further decreased. This is additional evidence that the kidneys can deal separately with these two most important ions of the extracellular fluid.

There is slight variability in stool sodium and chloride excretion. But considering the drastic changes in oral sodium and chloride intake from about 10 to $500 \mathrm{mEq}$. daily the stool losses remained surprisingly fixed and insignificantly small.
Fecal potassium excretion also showed no noteworthy variation.

Subject W. C. had one loose stool associated with abdominal cramps on the last day of sodium chloride administration. This one stool was collected and analyzed separately. Its sodium and chloride content was much higher than the remaining stools of that period.

Of greatest importance to this discussion are the observed changes in protein metabolism that occurred with variation of sodium intake. Figure 2 shows graphically the changes in nitrogen balance, urine urea excretion, blood urea nitrogen concentration, urine total uric acid excretion, urine potassium and phosphorus excretions in subject E. W. Exactly similar changes were observed in our other two subjects but because data are more complete in our last study on E. W. his results have been graphed. Sodium restriction is shown to produce slightly negative nitrogen balance during the first low sodium period. Following both periods of sodium administration the urine plus fecal nitrogen is considerably 


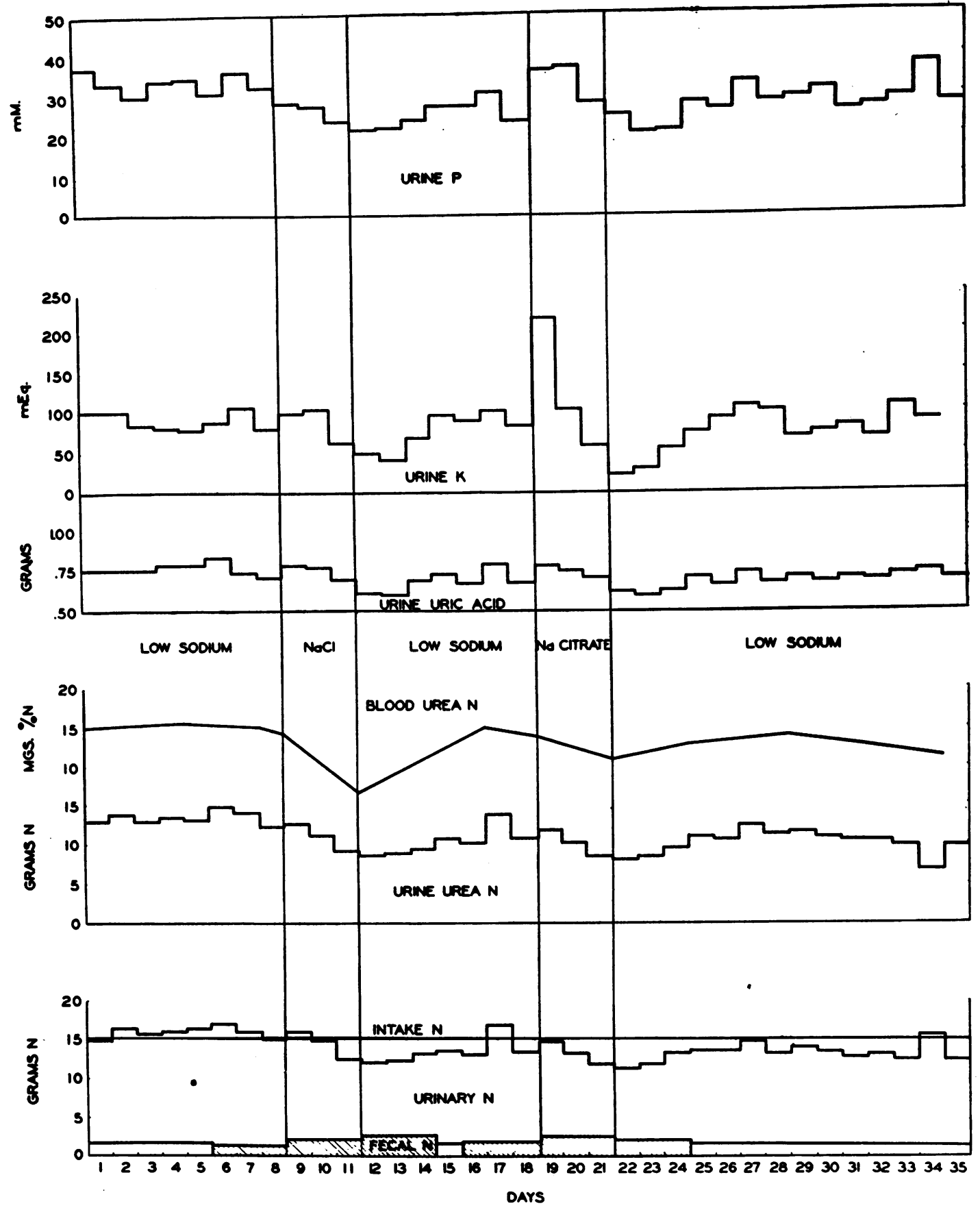

Fig. 2. To Show Changes in Nitrogen Balance, 24 Hour Urinary Urea, Uric Acid, Potassium, Phosphorus Excretions and Blood Urea Nitrogen Concentrations in Subject E. W.

The days of sodium chloride and sodium citrate administration are noted between parallel vertical lines. The hatched areas under "fecal $N$ " are values obtained by actual analyses of feces for total nitrogen content; the remainder of "fecal $N$ " is estimated. 
less than the intake of nitrogen so that nitrogen is stored in the body. The fecal nitrogen reveals that this decreased urinary nitrogen excretion was not the result of impaired nitrogen absorption from the alimentary tract.

Creatinine and ammonia excretion remained essentially constant so that the changes in urinary nitrogen excretion could be expected to be the result of changes in "metabolic" nitrogen. The urine urea excretion is seen to confirm this expectation since all changes in total urinary nitrogen are due almost entirely to changes in urine urea nitrogen (the difference between total urine nitrogen and urine urea nitrogen remaining very constant throughout the study).

That the changes in total and urea nitrogen excretion are not simply the result of storage of urea in the body fluids is indicated by the dramatic changes seen in the blood urea nitrogen. At the time when the urinary excretion of urea is at its lowest the blood urea concentrations are likewise lowest. Correcting the blood urea concentration for the dilution that might occur as the result of the increased body fluid volume produced by the sodium administration causes only insignificant changes. The serum creatinine was measured in the subject $\mathrm{E}$. W. and though it shows minor fluctuations it in no way parallels changes in blood urea level. It has been amply proven that the serum creatinine concentration is independent of the level of protein catabolism (26). As there has occurred no impairment of gastrointestinal absorption of nitrogen these changes can be interpreted only as the result of a decreased rate of urea production or a decreased catabolism of protein associated with administration of sodium to individuals previously maintained on low sodium diets. These effects on protein metabolism occur following both sodium citrate and sodium chloride administration and therefore are the result of the sodium rather than of the accompanying anion.

Urine uric acid excretion, urine potassium and phosphorus excretion mimic the changes in nitrogen metabolism exactly except for the very high rate of potassium excretion on the first day of sodium citrate administration. This change is believed to be due to effects other than those on protein metabolism (6). Serum potassium concentrations failed to show any evidence of increasing with the periods of low urine potassium excretion though unfortunately no serum potassiums were taken on the third or fourth days after the high sodium periods when this effect might have been present.

A point to be stressed is that there occurred a definite lag in the renal excretion of sodium during each high sodium period. Not until the third and last day of each high sodium period did the urinary excretion reach the level of the intake. Our interpretation of this lag is discussed below but here it should be noted that all the effects associated with the depressed protein catabolism were most pronounced immediately following rather than during the periods of high sodium administration, thus paralleling in this respect the lag in sodium excretion.

Urines were tested daily for reducing substance by the qualitative Benedict's test on subjects $M$. L. and E. W. but no evidence of glycosuria was noted. Glucose tolerance tests were done on subjects M. L. and E. W. M. L. showed no evidence of impaired glucose tolerance on the 11th day of the low sodium intake. (Standard glucose tolerance test after $1.75 \mathrm{gms}$. of glucose per kilogram of body weight revealed: fasting blood sugar -75 mgs. $\%$; one hour -71 mgs. $\%$; two hours -82 mgs. $\%$; three hours-51 mgs. $\%$; four hours56 mgs.\%.) E. W. on the 12th day of the final low sodium intake period showed: fasting blood sugar-89 mgs. $\%$; after one hour $-160 \mathrm{mgs} . \%$ second hour $-100 \mathrm{mgs} . \%$; third hour $-56 \mathrm{mgs} . \%$. A repeat glucose tolerance test on $\mathrm{E}$. W. two months after completion of this study and while on a normal dietary sodium intake revealed: fasting blood sugar-81 mgs. \%; after one hour-153 mgs. $\%$; after two hours-100 mgs. $\%$; and after three hours- 64 mgs. $\%$.

\section{DISCUSSION}

Changes in nitrogen metabolism similar to those reported here have been noted by others. In studying experimental sodium deficiency produced by a low sodium intake and sweating in normal subjects McCance (27) found that his subjects developed negative nitrogen balances with rise in blood urea concentration. This observation was striking enough to be emphasized by the author. In a subsequent publication, McCance and Widdowson (28) conclude that the main cause 
of this elevation of blood urea concentration with sodium depletion is the associated reduction in glomerular filtration rate. In another study McCance (29) observed that the administration of large doses of sodium chloride and sodium bicarbonate depressed the serum urea concentration significantly in previously dehydrated subjects. The electrolyte balance study of Albright and Bauer (30) on an edematous nephritic likewise shows an effect of administered sodium chloride and sodium bicarbonate on the nitrogen balance. Both sodium salts produced positive nitrogen balance. Landis et al. (31) reported striking changes in blood urea nitrogen levels in three subjects with varying degrees of renal insufficiency when the daily amount of sodium chloride intake was altered. Sodium chloride restriction caused increased blood urea nitrogen concentrations while administration of this salt lowered the concentration. These workers did 24 hour urea and creatinine clearances finding some increase in these clearances during the periods of sodium chloride administration. The decrease in blood urea nitrogen with administration of sodium chloride was associated with the increased renal clearances.

It is to be expected that administration of sodium chloride will increase glomerular filtration rate and hence urea clearance. Contrariwise, restriction of sodium intake in non-edematous patients with renal insufficiency is likely to produce severe dehydration through excessive renal loss of sodium with shrinkage of extracellular fluid volume. Hence, the increase in glomerular filtration rate with sodium administration is especially to be anticipated in patients with renal insufficiency (as were those of Landis $e t a l$.) who may be dehydrated prior to administration of the sodium.

The gain in weight observed in our subjects when sodium chloride was administered was almost entirely the result of an increase in extracellular fluid volume (as calculated from the gain in "chloride space" from the observed chloride balance). In such acute experiments as ours, changes in the hematocrit reflect changes in intravascular volume. Table IV clearly shows that sodium chloride administration results in a decrease in cell hematocrit with hemodilution. This increased intravascular volume may be expected, other factors remaining constant, to increase renal plasma flow with resulting increased glomerular
TABLE IV

E. $W$.

Hemodilution with increased rate of glomerular filtration following sodium chloride but not sodium citrate

\begin{tabular}{c|c|c|c|c}
\hline \hline Day & Hematocrit & $\begin{array}{c}\text { Total serum } \\
\text { protein }\end{array}$ & $\begin{array}{c}\text { 24 hour } \\
\text { creatinine } \\
\text { clearance }\end{array}$ & $\begin{array}{c}\text { 24 hour urea } \\
\text { clearance }\end{array}$ \\
\hline & \% cells & $\begin{array}{c}\text { gms. \% } \\
\text { liters }\end{array}$ & $\begin{array}{c}\text { liters } \\
1\end{array}$ \\
5 & 52 & 7.70 & 165 & 83 \\
8 & 52 & 7.42 & 157 & 84 \\
9 & & 7.27 & 165 & 79 \\
\hline
\end{tabular}

Period of sodium chloride administration

\begin{tabular}{r|l|l|l|r}
\hline 12 & 43 & 6.38 & 192 & 128 \\
15 & 48 & 7.19 & 133 & 90 \\
17 & 50 & & 153 & 92 \\
19 & 46 & 6.91 & 161 & 81 \\
\hline \multicolumn{4}{c}{ Period of sodium citrate administration } \\
\hline 22 & 44 & 6.50 & 161 & 76 \\
25 & 48 & 7.38 & 160 & 85 \\
29 & 47 & 7.19 & 155 & 85 \\
32 & 48 & 7.10 & 149 & 82 \\
\hline
\end{tabular}

filtration rate. Another aspect of the hemodilution is the decrease in total serum protein concentration also shown in Table IV. This decrease would cause a decreased colloid osmotic pressure of the serum which also, other factors remaining constant, would favor an increased rate of glomerular filtration. The creatinine clearance figures in Table IV taken as a measure of glomerular filtration rate $(32,33)$ in $E$. W. show this expected increase when sodium chloride is administered. An even proportionately greater increase in the 24 hour urea clearance is seen. This indicates a reduced rate of tubular reabsorption of urea in addition to the increase in glomerular filtration rate. This is to be expected with the greater rate of urine formation that followed the sodium chloride administration. Inulin clearance measurements of glomerular filtration rate in subject W. C. on the low sodium intake and immediately following the high sodium chloride period reveal exactly similar changes in glomerular filtration rate $(117 \mathrm{cc} / \mathrm{min}$. after 12 days of low sodium intake and $158 \mathrm{cc} . / \mathrm{min}$. the day after the sodium chloride administration) with the same evidence of increased plasma volume and hemodilution. Female subject M. L. however showed no significant change in inulin clearance (121 cc./ min. on the ninth day of low sodium intake and 123 
$\mathrm{cc} . / \mathrm{min}$. and $112 \mathrm{cc} . / \mathrm{min}$. on the days following the sodium chloride and sodium citrate period respectively). She also showed much less evidence of hemodilution than did the other two subjects. Sodium citrate produced no noteworthy changes in renal clearances in any subject.

Thus sodium chloride administration may to some degree lower the blood urea concentration by producing increased renal clearances in some cases. In our normal subjects the effect of altered renal dynamics on the blood urea concentration was, however, of lesser importance. In spite of the increased urea clearance in subjects E. W. and W. C. following sodium chloride, the 24 hour urea excretion was markedly reduced. The only way an increased clearance alone can decrease blood concentrations of a substance is by an increased rate of removal of that substance from the body fluids. But our data in all cases reveal a sharp decrease in the rate of urea and nitrogen excretion just at the time of lowest blood concentrations. Sodium citrate, which failed to increase the glomerular filtration rate, also produced a depression in blood urea concentration. In subject $M$. L. no noticeable increase in glomerular filtration rate was apparent on the day following administration of sodium chloride. However, the blood urea nitrogen depression still occurred.

In the presence of normal alimentary absorption of nitrogen and decreased renal excretion of it, the drop in blood concentrations of urea in our subjects must have been the result of a decreased rate of catabolism of protein. This accounted for the positive nitrogen balance resulting from administration of sodium. Figure 2 clearly shows that such an interpretation is justified.

The purpose of this study was to learn whether the physiological regulation of body sodium content is controlled by adrenal cortical activity in normal persons who ingest variable amounts of sodium. It has been amply demonstrated that the adrenal cortex produces hormones which are capable of decreasing renal sodium excretion $(1,5$, $34)$ and increasing catabolism of protein $(35,36)$. The former has a desoxycorticosterone-like action and has been termed the "salt-and-water" hormone (or hormones) while the latter is protein catabolic or anti-anabolic and will be called the "protein catabolic" hormone in this discussion.
This does not prove, however, that in the normal subject the desoxycorticosterone-like hormone actually controls sodium balance. But if these two apparently unrelated effects of adrenal cortical activity (i.e., on sodium and on protein) are elicited by the single stimulus to conserve body sodium, this will afford good evidence that the adrenal cortex is importantly involved in regulation of normal body sodium.

With these two actions of the adrenal cortex in mind, the changes noted in Figure 2 lend themselves readily to explanation on the basis of alterations of adrenal cortical activity as follows. In the first eight days of sodium restriction renal excretion of sodium decreased to a minimum under the stimulus of increased adrenal salt-and-water hormone activity. At the same time the rate of protein catabolism resulting from increased protein catabolic hormone activity caused a negative nitrogen balance with the levels of excretion of urea, uric acid and potassium as charted. Administration of large amounts of sodium chloride on the ninth, tenth and 11th days removed the requirement for renal conservation of sodium. The adrenal responded by decreasing the activity of its salt-andwater hormone output allowing the kidneys to increase their rate of sodium excretion enormously. At the same time the protein catabolic hormone was likewise depressed with decreased protein catabolism, a positive nitrogen balance, decreased uric acid, urea, potassium and phosphorus excretions. Further sodium restriction from the 12 th to 19th day resulted again in a decreased urine sodium excretion (increased adrenal activity). The following three day period of sodium citrate administration reproduces the same effects of decreased adrenal cortical function that occurred with sodium chloride administration, followed finally by increased adrenal cortical activity when sodium intake was again restricted during the final 14 days of the study.

Figure 3 was constructed from the observed potassium and phosphorus balances of subject $\mathrm{E}$. W. The theoretical potassium and phosphorus balances were calculated from the observed nitrogen balance. It is noted from this figure that the decreased potassium excretion that followed each period of sodium administration can only partially be accounted for by the decreased catabolism of protein that occurred at that time. Knowing that 
desoxycorticosterone, the salt-and-water hormone par excellence, produces an increased renal excretion of potassium $(37,38)$ while patients with Addison's disease and adrenalectomized animals have a decreased ability to excrete potassium (1, 39 ), this observed drop in potassium excretion is taken to be, at least in part, the result of a decreased salt-and-water hormone activity occurring at this time when there is a large renal sodium ex- cretion. Unfortunately, the serum potassium concentration was not determined immediately following the days of lowest urinary potassium excretion to ascertain whether or not an elevation of serum potassium occurred as a result of this decreased renal potassium excretion. The strikingly negative potassium balance on the first day of sodium citrate administration is discussed in another paper (6).

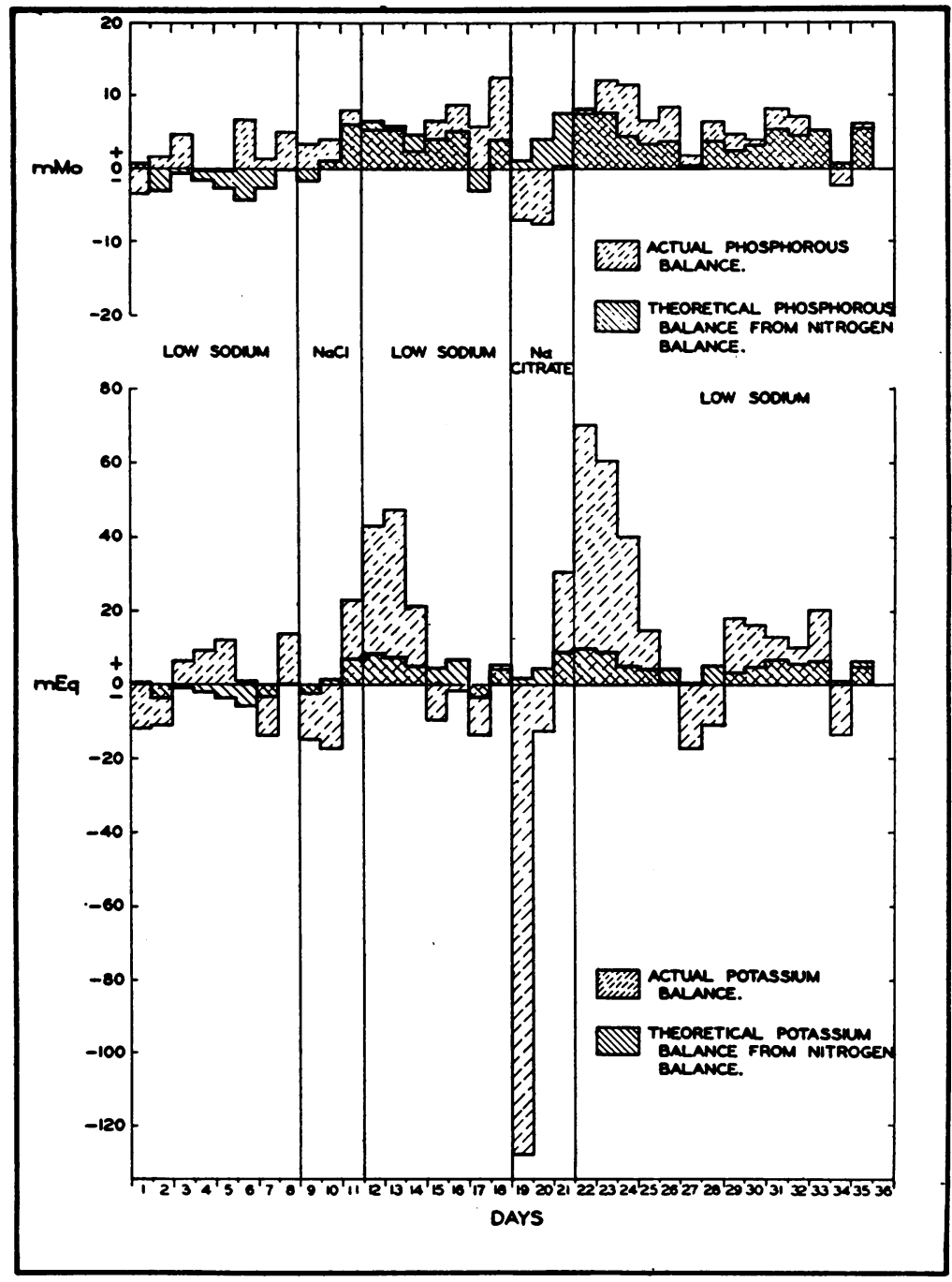

Fig. 3. The Actual and Theoretical Potassium (Lower) and Phosphorus (Upper) Balances Occurring in Subject E. W.

Output values were determined from the sum of urinary and fecal contents and intake values were obtained from diet analysis. The factor 2.7 was used to convert grams of observed nitrogen balance to milli-equivalents of "theoretical potassium balance" and the factor 2.15 to convert grams of observed nitrogen balance into millimols of "theoretical phosphorous balance." Note especially the large positive actual potassium balance immediately following both periods of sodium administration. 
A comparison of the phosphorus and nitrogen balances, also illustrated in Figure 3, reveals no significant differences between actual and theoretical phosphorus balance. The theoretical phosphorus balance was not, however, corrected for possible changes in bone metabolism.

Our data show more distinct evidence of depression of adrenal cortical activity with administration of sodium than stimulation of activity by restriction of sodium. However, with more severe sodium depletion produced by sweating in addition to very low sodium dietary intake, one of McCance's subjects had a negative nitrogen balance of $45 \mathrm{gms}$. in 11 days of sodium depletion and McCance states (27) “. . . this illustrated rather well the fact that the nitrogen balance steadily became more negative as sodium chloride was withdrawn from the body." Conn (40) found that sodium restriction in normal subjects undergoing acclimatization to humid heat results in negative nitrogen balance. This investigator demonstrated that it was the sodium restriction rather than a nonspecific effect of the hot environment which caused the negative nitrogen balance. Thus when acclimatization to the hot environment was complete in his subjects while they were on a fixed sodium intake, nitrogen balance was regained. Further restriction of sodium, without changing the exposure to the hot environment or otherwise altering the diet, was again followed by a negative nitrogen balance, which disappeared gradually as reacclimatization was accomplished on the lower sodium intake. Thus, it seems that the amount of evidence of increased protein catabolic hormone activity that is elicited in response to sodium restriction is dependent upon the intensity of the requirement to conserve body sodium.

It is also evident from our data that with prolongation of the period of low sodium intake the effects on nitrogen metabolism attributed to adrenal activity (protein catabolic hormone action) disappear. This occurs in spite of the continued renal conservation of sodium. In all three subjects the protein catabolic effects were most evident early in the study. As mentioned above, Conn (40) found that during acclimatization to a hot environment negative nitrogen balance occurs early and gradually disappears. It is of interest in this connection to note that Swanson and Smith
(41) found that rats kept on a "salt-free" diet showed a definite increase in weight of the adrenals followed by regression, with adrenal weights after 90 days only slightly greater than in the control rats receiving salt.

Apparently then, with continuation of the requirement to conserve body sodium, the protein catabolic hormone effect disappears. This could. be the result of a decreased adrenal cortical output of protein catabolic hormones or of a decreased response on the part of the tissues to the action of an increased protein catabolic hormone in the body. Our data give no clue as to whether one of the two or both possibilities actually occurs.

A further point of interest should be mentioned. That is the definite lag that occurred in the renal excretion of sodium when it was administered to our subjects following the low sodium intake, and the lag in the renal conservation of sodium that occurred when the sodium intake was again sharply reduced. Because the changes noted in nitrogen balance and renal potassium excretion with sodium administration show exactly the same lag, it appears that the sudden changes in sodium intake require some time to produce an adrenal response.

We are well aware that this interpretation of our results suffers considerably from the lack of adrenal cortical hormone assays which would more directly define the role of the adrenal cortex. ${ }^{3}$ However at the present time there is no method of measuring directly adrenal salt-and-water hormone production. Forsham et al. have found increased uric acid excretion to be a more consistent and more marked result of prolonged administration of 11 and 11-17 oxycorticosteroids than is the nitrogen balance (42). Further studies by this group of uric acid excretion in response to adrenocorticotrophin administration (43) support the view that uric acid excretion reflects changes in 11-oxycorticosteroid activity. The observed changes in total uric acid excretion in subject E. W. on a constant purine diet (see Figure 2) clearly then support our interpretation of altered adrenal cortical activity in response to varying sodium intake.

\footnotetext{
${ }^{3}$ Space does not permit a discussion of possible changes in androgenic and protein anabolic hormone activity of the adrenal cortex and our data show no positive evidence that such changes occurred.
} 
Because evidence of both protein catabolic hormone activity and of salt-and-water hormone activity has been elicited by the need to conserve body sodium it is suggested that the adrenal received its direct stimulus via the anterior pituitary. Studies with adrenocorticotropic hormone administration to human beings support this view since this hormone causes stimulation of protein catabolic effects as well as salt-and-water hormone effects $(40,43)$.

The fact that the changes observed were similar following both sodium chloride and sodium citrate administration indicates that the sodium cation is of importance rather than the anion. Just what change occurs in the body when sodium intake is restricted or high, which serves to initiate the adrenal cortical activity, is not revealed. Changes in concentration of extracellular fluid, sodium, chloride, $\mathrm{CO}_{2}$ content, tonicity of extracellular fluid or volume of extracellular fluid perhaps through its effect on circulating intravascular volume, all suggest themselves, but a multitude of other changes which occur in the extra- and intracellular fluids with variation in sodium intake might as likely act as the actual stimulus. The work of Selye on the general adaptation syndrome (44) suggests that our observations might simply cover an adaptation to sodium restriction as the stress, but this would only further describe rather than explain our results. Our findings and interpretation are in agreement with those of Conn (40), who demonstrated an increased adrenal cortical activity in response to the requirement to conserve salt during acclimatization to humid heat.

\section{SUMMARY AND CONCLUSIONS}

Some effects of marked variation in sodium intake in three normal young adult subjects were studied. These subjects were maintained on fixed diets containing adequate calories and protein with very low sodium and chloride content. At definite periods the sodium intake was abruptly increased by the addition of $480 \mathrm{mEq}$. of sodium as sodium chloride or sodium citrate.

With reduction from usual intakes of sodium to $9 \mathrm{mEq}$. of it daily there occurred an initial negative balance of sodium and chloride followed by progressive reduction of urinary losses to minimal amounts in about five days. This initial loss of body sodium and chloride was associated with a loss of about 2 kilograms of weight with subsequent stabilization of weight as urine sodium and chloride loss became very small. Slight decrease in serum sodium and chloride levels also occurred.

Administration of sodium as sodium chloride or as sodium citrate was accompanied by a sharp increase in body weight much more pronounced with sodium chloride than with the citrate. There also occurred a hemodilution as evidenced by decrease in serum proteins and hematocrit and an increased glomerular filtration rate. These latter effects were much more pronounced after sodium chloride administration than after sodium citrate.

A definite lag in the renal excretion of sodium with the shift from the low to the high sodium intake and a delay in the renal conservation of sodium with change from the high to the low sodium intake occurred.

With this variation in sodium intake definite changes in protein metabolism occurred. Administration of sodium after sodium restriction produced positive nitrogen balance while sodium restriction increased the rate of protein catabolism. These changes were reflected in increased 24 hour urea, uric acid, phosphorus and potassium excretions with sodium restriction and depression of these urinary excretions with sodium administration. In addition a definite decrease in blood urea concentration occurred with each period of sodium administration which could not be accounted for by alteration in renal clearance of urea but was the result primarily of a decrease in the rate of protein catabolism.

The decreased urinary potassium excretion following the periods of sodium administration could not be entirely accounted for by the decrease in protein catabolism that also occurred at this time and this effect is discussed.

We believe that all the observed effects are best explained by changes in adrenal cortical activity. In this sense the requirement for conservation of body sodium in the presence of a very low sodium intake was met by increased adrenal cortical activity of a desoxycorticosterone-like hormone, accompanied by increase in activity of adrenal protein catabolic hormone. Administration of large quantities of sodium abolished this need to prevent renal loss of sodium with resultant decrease in adrenal cortical activity. Our findings indicate that in the normal subject, the conserva- 
tion of body sodium by variation of renal excretion of sodium is the result of increased adrenal cortical activity in response to low sodium intake and decreased adrenal cortical activity when large amounts of sodium are administered.

\section{ACKNOWLEDGMENT}

The authors wish to acknowledge gratefully their appreciation to Dr. L. H. Newburgh whose interest and wise guidance made this study possible.

\section{BIBLIOGRAPHY}

1. Harrison, H. E., and Darrow, D. C., Renal function in experimental adrenal insufficiency. Am. J. Physiol., 1939, 125, 631.

2. Loeb, R. F., Atchley, D. W., Benedict, E. M., and Leland, J., Electrolyte balance studies in adrenalectomized dogs with particular reference to the excretion of sodium. J. Exper. Med., 1933, 57, 775.

3. Loeb, R. F., Effect of sodium chloride in treatment of patient with Addison's disease. Proc. Soc. Exper. Biol. \& Med., 1933, 30, 808.

4. Harrop, G. A., Weinstein, A., Soffer, L. J., and Trescher, J. H., Diagnosis and treatment of Addison's disease. J. A. M. A., 1933, 100, 1850.

5. Thorn, G. W., Garbutt, H. T., Hitchcock, F. A., and Hartman, F. A., The effect of cortin on the sodium, potassium, chloride, inorganic phosphorus and total nitrogen balance in normal subjects and in patients with Addison's disease. Endocrinology, 1937, 21, 202.

6. Leaf, A., Couter, W. T., and Newburgh, L. H., Some effects of variation of sodium intake in normal subjects. J. Clin. Invest., 1949, 28, 1082.

7. Wintrobe, M. M., Clinical Hematology. Lea \& Febiger, Philadelphia, 1942, p. 201.

8. Butler, A. M., and Tuthill, E., An application of the uranyl zinc acetate method for determination of sodium in biological material. J. Biol. Chem., 1931, 93, 171.

9. Peters, J. P., and Van Slyke, D. D., Quantitative Clinical Chemistry. Methods, Vol. II, p. 735. Williams \& Wilkins Co., Baltimore, 1932.

10. Shohl, A. T., and Bennett, H. B., A micro method for the determination of potassium as iodoplatinate. J. Biol. Chem., 1928, 78, 643.

11. Van Slyke, D. D., The determination of chlorides in blood and tissues. J. Biol. Chem., 1923, 58, 523.

12. Harvey, S. C., The quantitative determination of chlorides in the urine. Arch. Int. Med., 1910, 6, 12.

13. Peters, J. P., and Van Slyke, D.D., (Reference No. 9 above), p. 550 .

14. Ibid., p. 516.

15. Ibid., p. 602.

16. Bonsnes, R. W., and Taussky, H. H., On colorimetric determination of creatinine by Jaffe reaction. J. Biol. Chem., 1945, 158, 581.
17. Gentzkow, C., Accurate method for determination of blood urea nitrogen by direct nesslerization. J. Biol. Chem., 1942, 143, 531.

18. Barker, S. B., Direct colorimetric determination of urea in blood and urine. J. Biol. Chem., 1944, 152, 453.

19. Buchanan, O. H., Block, W. D., and Christman, A. A., The metabolism of the methylated purines. I. The enzymatic determination of urinary uric acid. J. Biol. Chem., 1945, 157, 181.

20. Van Slyke, D. D., and Neill, J. M., The determination of gases in blood and other solutions by vacuum extraction and manometric measurement. J. Biol. Chem., 1924, 61, 523.

21. Peters, J. P., and Van Slyke, D. D., (Reference No. 9 above), p. 530

22. Fiske, C. H., and Subbarow, Y., The colorimetric determination of phosphorus. J. Biol. Chem., 1925, 66, 375.

23. Goldring, W., and Chasis, H., Hypertension and Hypertensive Disease. Commonwealth Fund, New York, 1944, p. 198.

24. Bowes, A. deP., and Church, C. F., Food Values of Portions Commonly Used. A. deP. Bowes, Philadelphia, 1946.

25. McCance, R. A., and Widdowson, E. M., The Chemical Composition of Foods. Chemical Publishing Co., Inc., New York, 1947.

26. Barrett, E., and Addis, T., The serum creatinine concentration of normal individuals. J. Clin. Invest., 1947, 26, 875.

27. McCance, R. A., Experimental sodium chloride deficiency in man. Proc. Roy. Soc., Series B, 1936, 119, 245.

28. McCance, R. A., and Widdowson, E. M., The secretion of urine in man during experimental salt deficiency. J. Physiol., 1937, 91, 222.

29. McCance, R. A., The excretion of urea, salts and water during periods of hydropaenia in man. J. Physiol., 1945, 104, 196.

30. Albright, F., and Bauer, W., The action of sodium chloride, ammonium chloride and sodium bicarbonate on the total acid-base balance of a case of chronic nephritis with edema. J. Clin. Invest., 1929, 7, 465.

31. Landis, E. M., Elsom, K. A., Bott, P. A., and Shiels, E., Observations on sodium chloride restriction and urea clearance in renal insufficiency. J. Clin. Invest., 1935, 14, 525.

32. Steinitz, K., and Turkand, H., The determination of the glomerular filtration rate by the endogenous creatinine clearance. J. Clin. Invest., 1940, 19, 285.

33. Brod, J., and Sirota, J. H., The renal clearance of endogenous "creatinine" in man. J. Clin. Invest., 1948, 27, 645.

34. Thorn, G. W., Engel, L. L., and Eisenberg, H., Effects of corticosterone and related compounds on renal excretion of electrolytes. J. Exper. Med., 1938, 68, 161. 
35. Kendall, E. C., Hormones of the adrenal cortex. Endocrinology, 1942, 30, 853.

36. Long, C. N. H., A discussion of the mechanism of action of adrenal cortical hormones on carbohydrate and protein metabolism. Endocrinology, 1942, 30, 870.

37. Thorn, G. W., Howard, R. P., and Emerson, K., Jr., Treatment of Addison's disease with desoxycorticosterone acetate, a synthetic adrenal cortical hormone (preliminary report). J. Clin. Invest., 1939, 18, 449.

38. Thorn, G. W., Desoxycorticosterone. J. Mt. Sinai Hospital, 1942, 8, 1177.

39. Wilder, R. M., Kendall, E. C., Snell, A. M., Kepler, E. J., Rynearson, E. H., and Adams, M., Intake of potassium, an important consideration in Addison's disease. Arch. Int. Med., 1937, 59, 367.
40. Conn, J. W., The mechanism of acclimatization to heat, in: Advances in Internal Medicine. Interscience Publishers, Inc., New York, 1949.

41. Swanson, P. P., and Smith, A. H., Effect of restriction of inorganic salts in the diet on organ growth. Am. J. Physiol., 1936, 116, 516.

42. Forsham, P. H., Thorn, G. W., Bergner, G. E., and Emerson, K., Jr., Metabolic changes induced by synthetic 11-dehydrocorticosterone acetate. Am. J. Med., 1946, 1, 105.

43. Forsham, P. H., Thorn, G. W., Prunty, F. T. G., and Hills, A. G., Clinical studies with pituitary adrenocorticotrophin. J. Clin. Endocrinol., 1948, 8, 15.

44. Selye, H., The general adaptation syndrome and the diseases of adaptation. J. Clin. Endocrinol., 1946, 6, 117. 